\title{
PENGGUNAAN MEDIA AUDIO UNTUK MENINGKATKAN \\ KEMAMPUAN MENYIMAK DONGENG ANAK \\ PADA SISWA KELAS IV SEKOLAH DASAR
}

\author{
Heny Kusuma Widyaningrum \\ Prodi PGSD FIP IKIP PGRI MADIUN \\ h3nnycecan@gmail.com
}

\begin{abstract}
In elementary school, attentiveness is an important language skill. On the other hand, the fact shows that the lesson of attentiveness still low ang students' interest is poor. Thus, the use of proper media can be considered in order to make lessons' goal of attentive skill is approachable. Based on the above reason, this research purposes to improve attentive skill in myth in fourth grade students in SDN Sambirejo 1 Madiun by using audio media, that is myth recording. This research uses Classroom Action Research consist of two cycles. The result research shows the improvement on dispute the characters and the scene. Lessons' process is in these aspects: attention, seriousness, and activeness are improve up to $11,8 \%$. Result of improvement of attentive skill in myth in aspect characters and scene in the first cycle and second cycle are improve in average of 17,3\% and $7,4 \%$.
\end{abstract}

Key words: audio nedia, attentive skill, myth

\begin{abstract}
Abstrak
Di tingkat sekolah dasar, keterampilan menyimak merupakan keterampilan berbahasa yang penting. Namun, kenyataan di lapangan menunjukkan bahwa pembelajaran menyimak masih rendah dan kurangnya minat satra. Oleh karena itu, penggunaan media yang tepat perlu dipertimbangkan agar tujuan pembelajaran kemampuan menyimak tercapai. Berdasarkan hal tersebut, penelitian ini bertujuan meningkatkan kemampuan menyimak dongeng pada siswa kelas IV di SDN Sambirejo 01 Madiun dengan menggunakan media audio berupa rekaman dongeng. Penelitian ini menggunakan desain penelitian tindakan kelas yang terdiri atas dua siklus. Hasil penelitian tersebut menunjukkan peningkatan dalam menentukan isi dongeng mengenai tokoh dan latar dongeng. Proses pembelajaran pada aspek perhatian, keseriusan, dan keaktifan terjadi peningkatan sebesar $11.8 \%$. Hasil peningkatan kemampuan menyimak dongeng dari aspek tokoh dan latar pada siklus I ke siklus II terjadi peningkatan nilai rata-rata $17,3 \%$ dan $7,4 \%$.
\end{abstract}

Kata Kunci : media audio, kemampuan menyimak, dongeng 



\section{A. Pendahuluan}

Ruang lingkup mata pelajaran Bahasa Indonesia salah satunya penguasaan kebahasaan. Keterampilan kebahasaaan itu meliputi keterampilan menyimak, berbicara, membaca, dan menulis. Keterampilan menyimak merupakan keterampilan berbahasa yang penting dan harus diajarkan paling awal sebelum keterampilan berbahasa yang lain. Ariani, dkk (2009: 2) menjelaskan bahwa pelajar yang tidak pandai menyimak pelajaran yang diberikan guru akan mendapat kesukaran dalam mengikuti pelajarannya itu, bahkan besar sekali kemungkinannya gagal bagi mereka.

Rivers (dalam Ahmadi, 1990: 7) menjelaskan bahwa kebanyakan orang menggunakan waktunya dalam aktivitas komunikasi, yaitu 45\% digunakan untuk mendengarkan, 30\% untuk berbicara, $16 \%$ untuk membaca, dan hanya $9 \%$ untuk menulis. Sedangkan menurut Ariani, dkk (2009: 1), seseorang menggunakan waktu komunikasinya $50 \%$ untuk mendengarkan dan 50\% untuk berbicara, membaca, dan menulis. Berdasarkan hasil penelitian dari beberapa ahli tersebut menunjukkan bahwa kegiatan menyimak merupakan waktu yang paling banyak digunakan manusia dalam kehidupan sehari-hari. Sebelum anak melakukan keterampilan berbicara, membaca, dan menulis, kegiatan menyimak yang pertama dilakukan.

Selama proses komunikasi berlangsung di sekolah, siswa maupun guru harus menggunakan kemampuan menyimak dengan baik. Siswa harus dapat menangkap dan memahami dengan benar informasi yang disampaikan oleh guru atau siswa yang lainnya. Siswa yang tidak memiliki kemampuan mendengarkan yang efektif akan salah memahami atau menafsirkan informasi tersebut. Akibatnya, siswa akan memperoleh dan memiliki pengetahuan yang salah.

Penelitian ini memilih keterampilan menyimak untuk dijadikan objek penelitian karena dalam kegiatan belajar mengajar, guru sering menemui siswa yang kurang mampu memahami suatu materi yang diajarkan. Selain itu, ada kecenderungan keterampilan menyimak dalam bahasa Indonesia kurang mendapat perhatian dalam keseluruhan proses belajar bahasa Indonesia (Iskandarwassid \&Sunendar, 2008:229). Masalah tersebut dapat diatasi dengan kegiatan pembelajaran menyimak dengan baik dan benar.

Berdasarkan studi pendahuluan melalui kegiatan observasi dan wawancara terhadap guru bahasa Indonesia kelas IV di Sambirejo 01 Madiun, kemampuan siswa kelas IV pada keterampilan menyimak dongeng masih rendah. Hampir setengah dari seluruh kelas memperoleh nilai dibawah KKM. Hal ini disebabkan sumber belajar guru hanya bertumpu pada Lembar Kerja Siswa (LKS). Guru juga kurang kreatif dan hanya sekadar membacakan cerita tanpa ada ekspresi, intonasi, maupun jeda sehingga suasana kelas kurang menyenangkan dan daya tangkap siswa terhadap cerita yang didengar menjadi rendah. Pembelajaran dengan cara konvensional tersebut kurang efektif. Untuk mengatasi masalah tersebut, diperlukan media pembelajaran yang tepat sehingga siswa dapat menguasai kompetensi yang diharapkan. 
Prastowo (2011: 264) menjelaskan bahwa media ajar audio adalah salah satu jenis bahan ajar noncetak yang di dalamnya mengandung sistem yang menggunakan sinyal audio secara langsung yang dapat diperdengarkan oleh pendidik kepada peserta didiknya guna membantu mereka dalam menguasai kompetensi tertentu. Penggunaan media audio juga dapat membantu menutupi kekurangan penampilan guru ketika menyampaikan cerita, seperti suara lirih/kecil, intonasi kurang jelas, dan kondisi fisik yang lelah saat mengajar. Selain itu, cerita akan lebih menarik dan hidup karena diselingi dengan musik dan efek suara sesuai dengan runtutan cerita sehingga dapat membantu siswa untuk dapat menikmati cerita yang didengar dengan daya imajinasi dan konsentrasi.

Berdasarkan uraian di atas dan informasi mengenai proses kegiatan pembelajaran bahasa Indonesia kelas IV di SDN Sambirejo 01 Madiun, secara nyata menjadi dasar bagi peneliti untuk melaksanakan penelitian yang berjudul "Penggunaan Media Audio untuk Meningkatkan Kemampuan Menyimak Dongeng Anak di Kelas IV SDN Sambirejo 01 Madiun”.

\section{B. Metode Penelitian}

Penelitian yang berjudul "Penggunaan Media Audio untuk Meningkatkan Kemampuan Menyimak Dongeng Anak di Kelas IV SDN Sambirejo 01 Madiun" menggunakan pendekatan kualitatif. Sesuai dengan pernyataan Moleong (1999:27) bahwa penelitian kualitatif itu berakar alamiah sebagai keutuhan, mengandalkan manusia sebagai alat penelitian, memanfaatkan metode kualitatif, mengadakan analisis data secara induktif, mengarahkan sasaran penelitiannya pada usaha menemukan teori dari dasar, bersifat deskriptif, lebih mementingkan proses daripada hasil, membatasi studi dengan fokus, memiliki seperangkat kriteria untuk memeriksa keabsahan data, rancangan penelitiannya bersifat sementara, dan hasil penelitiannya disepakati oleh kedua belah pihak: peneliti dan subjek penelitian.

Penelitian diawali dengan studi pendahuluan yang berisi kegiatan pencarian informasi tentang keadaan pembelajaran menyimak di sekolah. Penelitian tindakan dipilih untuk mendeskripsikan proses pembelajaran di kelas, terutama peningkatan kemampuan menyimak dengan menggunakan media audio yang dilakukan oleh siswa. Berdasarkan tujuan tersebut maka digunakan jenis penelitian tindakan kelas atau classroom action research.

Penelitian tindakan kelas merupakan tindak lanjut dari penelitian deskriptif dan penelitian eksperimen karena penelitian tindakan ini sudah lebih jauh ke depan (Arikunto, 2006: 96). Penelitian tindakan tidak sekedar mengetes tapi juga berkeyakinan untuk menerapkannya dengan mengikuti proses serta dampak perlakuannya (Arikunto, 2006:96). Keseluruhan tahap tersebut, secara garis besar dapat dilihat dalam bagian berikut. 


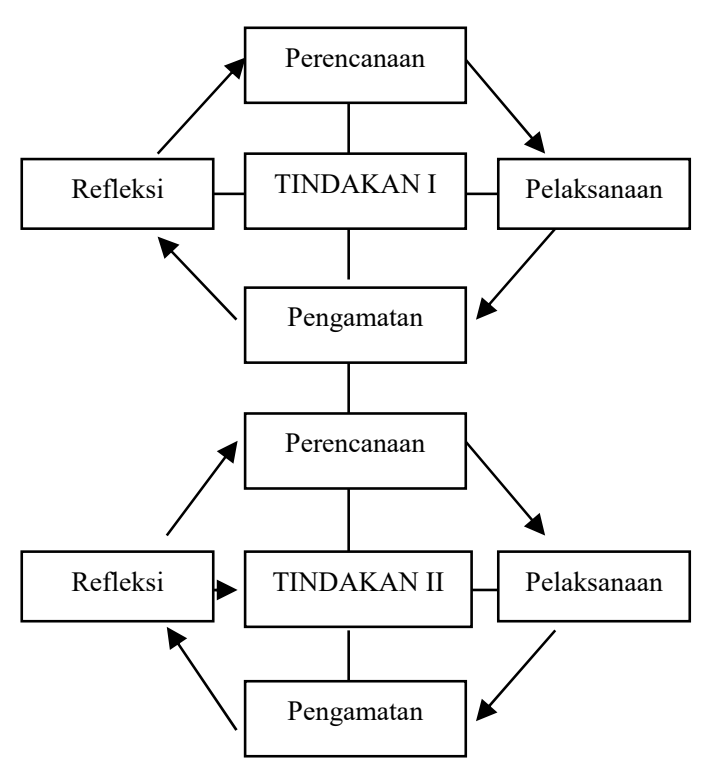

Gambar Bagan Model PTK menurut Arikunto (2006: 97)

Teknik pengumpulan data yang digunakan adalah teknik tes dan nontes. Teknik tes digunakan untuk mengetahui aktifitas belajar serta tingkat kemampuan siswa dalam menyimak cerita anak. Teknik nontes digunakan untuk mengetahui permasalahan yang ada dalam pembelajaran bahasa Indonesia yaitu dengan observasi secara langsung, dokumentasi, wawancara, serta untuk mengetahui respon siswa sebelum dan setelah penggunaan media audio. Sedangkan instrumen yang digunakan, yaitu pedoman rencana pembelajaran, observasi, , wawancara, dokumentasi, lembar kegiatan siswa dan tes.

Menurut Tim peneliti proyek PGSM (dalam Muslich, 2009: 159). Teknik analisis data dilakukan melalui 3 tahap, yaitu reduksi data, paparan data, dan penyimpulan. Reduksi data adalah proses penyederhanaan data yang diperoleh melalui pengamatan dengan cara memilih data sesuai dengan kebutuhan penelitian. Pemilihan data tersebut, kemudian dipaparkan lebih sederhana menjadi paparan yang berurutan berupa paparan data yang akhirnya ditarik kesimpulan dalam bentuk pernyataan kalimat yang singkat dan padat. Data pada penelitian ini adalah data aktifitas belajar siswa dan hasil tes kemampuan menyimak dongeng.

\section{Hasil Penelitian}

Penelitian ini dilaksanakan sebanyak dua siklus untuk meningkatkan kemampuan menyimak dongeng kelas II pada kompetensi dasar menceritakan kembali isi dongeng yang diperdengarkan. Perencanaan siklus I, yaitu (1) menyusun lembar wawancara guru,(2) menyusun Rencana Pelaksanaan Pembelajaran (RPP) siklus I untuk 1 kali pertemuan, (3) membuat rekaman dongeng anak,(4) menyusun lembar penilaian proses dan hasil dari isi dongeng yang diperdengarkan, dan (5) menyusun lembar observasi aktivitas guru dan siswa.

Pelaksanaan tindakan dan observasi pada siklus dimulai dengan menggali kemampuan awal siswa dengan cara bertanya jawab. Selanjutnya, guru memperdengarkan rekaman dongeng. Kegiatan menyimak usai dan siswa ditugaskan untuk menemukan tokoh dan latar dalam dongeng. Setelah itu,siswa dan guru melakukan tanya jawab berkaitan dengan isi dongeng. Setelah proses pemberian materi usai, guru memperdengarkan lagi dongeng sebagai bahan tes evaluasi.

Pada tahap akhir, kegiatan dilaksanakan sesuai dengan rencana pembelajaran. Kegiatan akhir tersebut meliputi ulasan dari guru tentang 
kegiatan yang telah dilaksanakan serta penguatan dan refleksi terhadap pembelajaran menyimak dongeng dengan menggunakan media rekaman dongeng. Dari hasil wawancara antara guru dengan beberapa siswa, menunjukkan bahwa siswa menyukai dan atusias ketika melakukan pembelajaran menggunakan media rekaman dongeng.

Perencanaan siklus II, yaitu (1) lebih menekankan penjelasan tentang isi dongeng (tokoh dan latar,), (2) membuat rekaman dongeng anak untuk evaluasi, (3) menumbuhkan motivasi siswa dalam bertanyajawab dengan memberikan pujian bagi siswa yang berani bertanya dan menjawab,dan (4) memberikan penekanan kepada siswa agar lebih tertib dalam melaksanakan setiap kegiatan pembelajaran.

Pembelajaran dimulai dengan membahas rekaman dongeng yang telah dilakukan pada siklus I. Guru menjelaskan kesalahan-kesalahan yang dilakukan oleh siswa dan bertanya kesulitan-kesulitan yang mereka rasakan ketika mengikuti pembelajaran menyimak dongeng dengan menggunakan media audio. Pada kegiatan ini, sebagian besar siswa terlihat aktif dalam kegiatan tanya jawab. Selanjutnya, guru memperdengarkan rekaman dongeng berjudul kembali dengan judul yang berbeda.
Kegiatan menyimak usai dan siswa ditugaskan untuk menemukan isi dongen segi tokoh, latar, dan alur yang terkandung di dalam dongeng tersebut Sebelum melaksanakan kegiatan tersebut, guru memberikan motivasi kepada siswa. Setelah memberikan motivasi tersebut, sebagian besar siswa mulai mengacungkan tangan untuk menjawab pertanyaan.

Setelah proses pemberian materi usai, guru memperdengarkan lagi dongeng sebagai bahan tes evaluasi. Kegiatan akhir tersebut meliputi ulasan dari guru tentang kegiatan yang telah dilaksanakan serta penguatan dan refleksi terhadap pembelajaran menyimak dongeng dengan menggunakan media rekaman dongeng anak. Berdasarkan hasil observasi guru diketahui bahwa siswa memperhatikan dengan baik penjelasan dari guru pembelajaran menyimak dongeng menggunakan media rekaman dongeng anak. Siswa juga terlihat sangat antusias ketika guru

Berdasarkan hasil temuan penelitian maka dilakukan evaluasi terhadap proses tindakan yang akan dicapai. Aspek yang dinilai dalam penilaian proses adalah aspek perhatian, aspek keseriusan, dan aspek keaktifan. Dengan melihat proses tersebut, kemudian dicocokan dengan kriteria yang ditetapkan, akan diperoleh hasil evaluasi yang sesuai dengan harapan atau belum. Berikut adalah rincian evaluasi proses pada siklus 1 dan siklus 2. 
Tabel 1 Data Proses Pembelajaran Siklus 1

\begin{tabular}{llcccl}
\hline No & \multicolumn{1}{c}{ Aspek Penilaian Proses } & $\begin{array}{c}\text { Target } \\
\text { Proses }\end{array}$ & $\begin{array}{c}\text { Peningkatan Proses } \\
\text { Kondisi } \\
\text { Awal }\end{array}$ & $\begin{array}{c}\text { Siklus } \\
\text { I }\end{array}$ & \\
\hline 1 & $\begin{array}{l}\text { Perhatian siswa pada pembelajaran } \\
\text { menyimak dongeng. }\end{array}$ & $75 \%$ & $71,4 \%$ & $77,3 \%$ & Tercapai \\
\hline 2 & $\begin{array}{l}\text { Keseriusan siswa dalam pembelajaran } \\
\text { menyimak dongeng. }\end{array}$ & $75 \%$ & $70,3 \%$ & $76,2 \%$ & Tercapai \\
\hline 3 & $\begin{array}{l}\text { Keaktifan siswa dalam bertanya jawab } \\
\text { pada pembelajaran menyimak dongeng. }\end{array}$ & $75 \%$ & $67,8 \%$ & $70,3 \%$ & $\begin{array}{l}\text { Belum } \\
\text { Tercapai }\end{array}$ \\
\hline Rata-rata & $75 \%$ & $69,8 \%$ & $74,6 \%$ & \\
\hline
\end{tabular}

Tabel 2 Data Proses Pembelajaran Siklus II

\begin{tabular}{|c|c|c|c|c|c|}
\hline \multirow[b]{2}{*}{ No } & \multirow[b]{2}{*}{ Aspek Penilaian Proses } & \multicolumn{3}{|c|}{$\begin{array}{c}\text { Capaian } \\
\text { Target Peningkatan Proses }\end{array}$} & \multirow[b]{2}{*}{-Keterangan } \\
\hline & & Proses & $\begin{array}{c}\text { Kondisi } \\
\text { Awal }\end{array}$ & $\begin{array}{l}\text { Siklus } \\
\text { I }\end{array}$ & \\
\hline 1 & $\begin{array}{l}\text { Perhatian siswa pada pembelajaran } \\
\text { menyimak dongeng. }\end{array}$ & $75 \%$ & $71,4 \%$ & $80,3 \%$ & Tercapai \\
\hline 2 & $\begin{array}{l}\text { Keseriusan siswa dalam pembelajaran } \\
\text { menyimak dongeng. }\end{array}$ & $75 \%$ & $70,3 \%$ & $83,6 \%$ & Tercapai \\
\hline 3 & $\begin{array}{l}\text { Keaktifan siswa dalam bertanya jawab } \\
\text { pada pembelajaran menyimak dongeng. }\end{array}$ & $75 \%$ & $67,8 \%$ & $80,8 \%$ & Tercapai \\
\hline Rat: & a-rata & $75 \%$ & $75 \%$ & $69,8 \%$ & $81,6 \%$ \\
\hline
\end{tabular}

Evaluasi kemampuan siswa dalam menemukan isi dongeng siklus I yang didasarkan pada deskriptor sesuai dengan kunci jawaban dapat dilihat pada tabel berikut.

Tabel 3 Skor Penilaian Indikator Isi Dongeng tentang Tokoh

\begin{tabular}{|c|c|c|c|c|c|}
\hline No & Kategori & Skor & Frekuensi & $\%$ & Keterangan \\
\hline 1 & Tuntas & $74,5-100$ & 21 & 70 & \multirow{3}{*}{$\begin{array}{l}\text { Rata-rata } \\
2160: 30=72 \\
\text { Presentase } 72 \% \\
\text { Hasil secara klasikal } \\
\text { berkategori tuntas }\end{array}$} \\
\hline 2 & Belum Tuntas & $0-74,4$ & 9 & 30 & \\
\hline \multicolumn{3}{|c|}{ Jumlah } & 30 & 100 & \\
\hline
\end{tabular}

Tabel 4 Skor Penilaian Indikator Isi Dongeng tentang Tokoh

\begin{tabular}{|c|c|c|c|c|c|}
\hline No & Kategori & Skor & Frekuensi & $\%$ & Keterangan \\
\hline 1 & Tuntas & $74,5-100$ & 28 & 93 & \multirow{3}{*}{$\begin{array}{l}\text { Rata -rata } \\
\text { 2530: } 30=84,3 \\
\text { Presentase } 84,3 \% \\
\text { Hasil secara klasikal } \\
\text { berkategori tuntas }\end{array}$} \\
\hline 2 & Belum Tuntas & $0-74,4$ & 2 & 7 & \\
\hline \multicolumn{3}{|c|}{ Jumlah } & 30 & 100 & \\
\hline
\end{tabular}


Dari tabel diatas, diketahui bahwa siswa yang mencapai kategori tuntas

dengan rentang skor 74,5-100 sebanyak 28 siswa atau sebesar 93\%. Untuk kategori belum tuntas dengan rentang skor 0-74,4 dicapai oleh 2 siswa atau sebesar $93 \%$. Skor rata-rata untuk indikator ini adalah 84,3 atau 84,3 \%dengan kategori tuntas. Berdasarkan paparan diatas, maka dapat disimpulkanbahwa terjadi peningkatan sebesar $12,3 \%$ jika dibandingkan dengan hasil tindakan I.

Evaluasi kemampuan siswa dalam menemukan isi dongeng dari latar dongeng siklus I dan II didasarkan pada deskriptor sesuai dengan kunci jawaban dapat dilihat pada tabel berikut.

Tabel 5 Skor Penilaian Indikator Isi Dongeng tentang Latar

\begin{tabular}{llcccl}
\hline No & Kategori & Skor & Frekuensi & $\mathbf{\%}$ & \multicolumn{1}{c}{ Keterangan } \\
\hline 1 & Tuntas & $74,5-100$ & 22 & 73 & $\begin{array}{l}\text { Rata-rata } \\
2268: 30=75,6 \\
\text { Presentase } 75,6 \%\end{array}$ \\
\hline 2 & Belum Tuntas & $0-74,4$ & 8 & 27 & $\begin{array}{l}\text { Hasil secara klasikal } \\
\text { berkategori tuntas }\end{array}$ \\
\hline
\end{tabular}

Tabel 6 Skor Penilaian Indikator Isi Dongeng tentang Latar

\begin{tabular}{llcccl}
\hline No & Kategori & Skor & Frekuensi & \% & \multicolumn{1}{c}{ Keterangan } \\
\hline 1 & Tuntas & $74,5-100$ & 27 & 90 & $\begin{array}{l}\text { Rata-rata } \\
2490: 30=83 \\
\text { Presentase } 83 \%\end{array}$ \\
\hline 2 & Belum Tuntas & $0-74,4$ & 3 & 10 & $\begin{array}{l}\text { Hasil secara klasikal } \\
\text { berkategori tuntas }\end{array}$ \\
\hline
\end{tabular}

Dari tabel diatas dapat diketahui bahwa siswa yang mencapai kategori tuntasdengan rentang skor 74,5-100 sebanyak 27 siswa atau sebesar 90\%. Untuk kategori belum tuntas dengan rentang skor $0-74,5$ dicapai oleh 3 siswa atau

sebesar $10 \%$. Skor rata-rata untuk indikator ini adalah 83atau $83 \%$ dengan kategori tuntas. Berdasarkan paparan diatas, maka dapat disimpulkan bahwa terjadi peningkatan sebesar 7,4\% jika dibandingkan dengan hasil tindakan I.

\section{Pembahasan}

Ketercapaian pelaksanaan proses pembelajaran pada siklus I jika ditinjau dari aspek perhatian dan kesungguhan diperoleh hasil yang baik. Hal itu disebabkan penggunaan media audio adalah hal yang baru dilakukan pada mata pelajaran Bahasa Indonesia di SDN Sambirejo 01 Madiun. Selaras dengan pendapat Slameto (2003:106) bahwa perhatian diarahkan pada hal-hal yang baru, hal-hal yang berlawanan dengan pengalaman yang baru saja diperoleh atau dengan pengalaman yang didapat selama hidupnya. Perhatian dan kesungguhan siswa yang baik akan membuatnya memahami konsep 
pembelajaran yang diajarkan oleh guru serta memudahkan menerima tugas-tugas. Sedangkan dari aspek keaktifan dirasakan masih kurang. Hal ini disebabkan kurangnya motivasi dari guru kurangnya tingkat kepercayaan diri siswa. Oleh karena itu, siswa tidak berani mengungkapkan ide, pendapat, dan pikirannya karena takut salah.

Ketercapaian pelaksanaan proses pembelajaran siklus 1 diperoleh hasil yang baik apabila dibandingakan dengan siklus I. Hal ini disebabkan menyimak rekaman dongeng melatih sikap siswa ketika proses menyimak, yakni lebih fokus dan konsentrasi. Keterampilan menyimak yang baik menyangkut sikap, ingatan, persepsi, kemampuan membedakan, intelegnsi, perhatian, motivasi, dan emosi yang harus dikerjakan secara integral dalam tindakan yang optimal pada saat pembelajaran berlangsung (Soedjiatno, 1992:5).Aspek keaktifan tercapai sekitar 80,8 siswa yang aktif dalam kegiatan bertanya jawab. Peningkatan ini terjadi karena guru memberikan motivasi dan membangun rasa percaya diri pada siswa, sehingga mereka menjadi lebih berani dalam mengungkapkan ide, pendapat, dan pikirannya tanpa takut dimarahi karena salah.

Setelah dilakukan

pembelajaran menyimak dongeng dengan media audio, hasil proses pembelajaran menyimak dongeng pada siklus II ini mengalami peningkatan dari Standar Ketuntasan Minimal (SKM. Oleh karena itu, guru dan peneliti dapat dikatakan berhasil dalam menuntaskan proses pembelajaran menemukan hal-hal menarik dari dongeng yang diperdengarkan dengan menggunakan media rekaman dongeng anak.

Kemampuan siswa dalam menentukan isi dongeng pada siklus I dapat dilihat dari hasil analisis tes evaluasi siswa sudah dapat menemukan tokoh-tokoh tokoh dari dongeng yang diperdengarkan. Namun, dalam menemukan tokoh, masih ada beberapa siswa yang memperoleh nilai di bawah SKM. Pada siklus I ada beberapa siswa (30\%) yang memperoleh nilai di bawah SKM karena mereka kurang berkonsentrasi. Pemutaran media dongeng pertama masih terfokus pada suara atau efek-efek suara dan alur ceritanya.

Pada siklus II siswa sudah dapat menemukan tokoh- tokoh dongeng dengan baik dan tepat. Siswa sudah mampu menyebutkan tokoh-tokoh yang diperdengarkan melalui media rekaman dongeng. Hal ini dikarenakan siswa lebih berkonsentrasi agar mampu menjawab tokoh-tokoh dongeng dengan tepat. Dari 30 siswa, 28 siswa atau sebesar 93\% mencapai kategori tuntas dan 2 siswa atau sebesar $7 \quad \%$ memperoleh kategori belum tuntas, dan rata-rata kelas naik sebesar 12,3\%. Berdasarkan pemaparan diatas maka dapat disimpulkan bahwa penggunaan media audio anak efektif dalam meningkatkan kemampuan menyebutkan tokoh-tokoh dongeng.

Kemampuan siswa dalam menentukan aspek latar siklus I dapat dilihat dari hasil analisis tes evaluasi siswa mencapai $73 \%$. Masih ada delapan siswa di bawah SKM yang belum tepat menyebutkan latar dengan benar. Latar atau setting adalah penggambaran situasi tempat dan waktu serta suasana 
terjadinya peristiwa dan latar berfungsi sebagai pendukung alur dan perwatakan (Suroto, 1989:94). Siswa yang dibawah SKM kurang tepat menyebutkan situasi cerita dengan baik.

Pada siklus II siswa sudah mampu menyebutkan latar dongeng. Dari 30 siswa, 27 siswa atau sebesar $90 \%$ mencapai kategori tuntas dan 3 siswa atau sebesar $10 \%$ memperoleh kategori belum tuntas, dan rata-rata kelas naik sebesar 7,4\%. Ditinjau dari keberhasilan yang telah dicapai siswa, disimpulkan bahwa kemampuan menyimak dapat dikuasai siswa dengan cara berlatih. Menyimak merupakan keterampilan yang dapat dilatihkan yaitu dengan cara memberi latihan menyimak berbagai ragam wacana lisan (Zahro dan Sulistyorini, 2010:24). Berdasarkan pemaparan diatas maka, disimpulkan penggunaan media audio efektif dalam meningkatkan kemampuan menemukan hal-hal menarik dari aspek latar dongeng.

\section{E. Simpulan}

Peningkatan tersebut tidak hanya terlihat pada proses pembelajaran, juga pada hasil pembelajaran siswa. Perilaku siswa kelas IV SDN Sambirejo 01 Madiun setelah mengikuti pembelajaran menyimak dongeng melalui media audio mengalami perubahan ke arah positif. Perubahan tersebut terlihat pada aspek perhatian siswa selama pembelajaran berlangsung. Terbukti adanya peningkatan karena penggunaan media audio memberikan daya tarik dan sebagai sarana belajar menyimak yang berguna untuk kegiatan belajar mengajar siswa. Ditinjau dari aspek keaktifan, siswa selama pembelajaran berlangsung tampak ada perubahan positif setelah dilaksanakan pembelajaran menyimak melalui media. Dengan demikian, terlihat bahwa penggunaan media audio dalam pembelajaran menyimak dapat memacu motivasi siswa sehingga siswa menjadi lebih perhatian, serius, dan aktif.

Kemampuan menyimak dongeng pada siswa mengalami peningkatan setelah melakukan pembelajaran menyimak dongeng melalui media audio. Hal tersebut dibuktikan dengan melihat hasil tes evaluasi dengan menyebutkan isi dongeng berupa penyebutan tokoh-tokoh dan latar. Perolehan hasil ini menunjukkan bahwa pembelajaran menyimak dongeng melalui media audio, berhasil meningkatkan kemampuan menyimak dongeng siswa kelas IV SDN Sambirejo 01 Madiun.

\section{F. Saran}

Berdasarkan simpulan hasil pembelajaran, penggunaan media audio dalam pembelajaran menyimak dapat memacu motivasi siswa sehingga siswa menjadi lebih perhatian, keseriusan, serta keaktifan siswa dalam belajar. Guru hendaknya memberikan pembelajaran yang bervariasi agar menumbuhkan minat dan ketertarikan siswa dalam pembelajaran menyimak, misalnya dengan penggunaan media audio dalam pembelajaran menyimak.

$$
\text { Hasil proses pembelajaran }
$$
setelah mengikuti pembelajaran menyimak dongeng melalui media audio, siswa mengalami perubahan ke arah positif. Penggunaan media audio dapat direkomendasikan pada guru 
bahasa Indonesia sebagai salah satu media untuk membelajarkan kemampuan menyimak, khususnya menyimak cerita yang lain karena telah terbukti mampu meningkatkan kemampuan menyimak dongeng dan mampu mengubah perilaku siswa ke arah yang positif.

\section{Daftar Pustaka}

Ahmadi, Mukhsin. 1990. Keterampilan Berbahasa \& Apresiasi Sastra. Malang: YA3.

Ariani, Farida, dkk. 2009. Pembelajaran

Mendengarkan. Depdiknas: Pusat Pengembangan dan Pemberdayaan Pendidik dan Tenaga Pendidikan Bahasa.

Arikunto, Suharsimi. 2006.

Prosedur Penelitian Suatu Pendekatan Praktek. Jakarta : Rineka Cipta

Iskandarwassid, \& Sunendar, Dadang. 2008. Strategi
Pembelajaran Bahasa. Bandung: Rosdakarya.

Moleong, Lexy J. 1999. Metodologi Penelitian Kuantitatif. Bandung: PT Remaja Rosda Karya.

Muslich, Masnur. 2009. Melaksanakan Penelitian Tindakan Kelas Itu Mudah. Malang: Bumi Aksara.

Prastowo, Andi. 2011. Panduan Kreatif Membuat Bahan Ajar Inovatif. Yogyakarta: DIVA Press.

Slameto. 2003. Belajar dan FaktorFaktor yang Mempengaruhinya. Jakarta: Penerbit Rineka Cipta.

Soedjiatno. 1992. Keterampilan Menyimak dan Pengajarannya $I$. Malang: Departemen Pendidikan dan Kebudayaan IKIP Malang

Suroto,1989. Apresiasi Sastra Indonesia: untuk SMU. Jakarta: Erlangga.

Zahro, Azizatul \& Sulistyorini, Dwi. 2010.Strategi Kooperatif dalam Pembelajaran Menyimak dan Berbicara. Malang: Asis Asah Asuh. 